\title{
They are Communities like You: The Rationale for Animal Rights and Welfare in Islamic Civilization ${ }^{*}$
}

\author{
Necmettin Kızılkaya
}

\begin{abstract}
Animal treatment has a comprehensive connotation and far-reaching implications in Islamic civilization. The rationes leges for this broader meaning in human-animal relations are the principles laid out in the two foundational sources of Islam, i.e., the Qur'ān and the Sunnah of the Prophet Muhammad. While dealing with the subject of animals, different disciplines carried the framework drawn in these two sources to a more abstract level, thereby becoming the very basis for practices in societies' daily life. One of these disciplines, Islamic jurisprudence deals with how people are to preserve the God-given rights of animals while extracting benefit from in different chapters. In this article, I will first provide a brief introduction to animal welfare and protection in Islamic civilization. I will then focus on how scholars have interpreted the Qur' ānic concept of community (ummah, plural: umam) in exegetical literature. After that, I will show how the Prophet Muhammad's approach of gentleness (rifq) and excellence (iḥsān) manifested in his treatment of animals through several examples from the hadith literature. Finally, I will attempt to demonstrate how Islamic jurisprudence embodies this theoretical framework through the concept of harm. In conclusion, I will show that there are important concepts and examples in Islamic thought that shed light on scholarship in the field of animal studies.
\end{abstract}

Keywords: Animal welfare, animal care, animal protection, Islamic law, excellence, gentleness, harm.

Öz: Hayvanlara muamele İslam medeniyetinde çok kapsamlı bir konudur. İnsan-hayvan ilişkilerindeki bu geniş anlamın fikri temelleri, İslam'ın iki temel kaynağı olan Kur'an ve sünnette ortaya konan ilkelerdir. Farklı disiplinler hayvanlar konusunu ele alırken, bu iki kaynakta çizilen çerçeveyi daha soyut bir düzeye taşıdı ve bu toplumların günlük yaşamındaki uygulamalarının temelini oluşturdu. Bu disiplinlerden biri olan İslam hukuku, insanların Allah tarafından hayvanlara verilmiş haklarını nasıl koruyacakları ve onlardan nasıl yararlanacakları ile ilgilenir. Bu yazıda öncelikle İslam medeniyetinde hayvan refahı ve hayvanların korunmasına dair kısa bir giriş yapacağım. Daha sonra tefsir literatüründe Kur'an'ın hayvanlar için kullandığı ümmet kavramını nasıl yorumladıklarına odaklanacağım. Bundan sonra $\mathrm{Hz}$. Muhammed'in rıfk ve ihsan yaklaşımının hadis literatüründen bazı örneklerle hayvanlara muamelesinde nasıl tezahür ettiğini göstereceğim. Son olarak, zarar kavramı bağlamında İslam hukukunun bu teorik çerçeveyi nasıl somutlaştırdığını göstermeye çalışacağım. Sonuç olarak İslam düşüncesinde hayvan çalışmaları alanındaki araştırmalara ışık tutan önemli kavram ve örneklerin olduğunu göstereceğim.

Anahtar Kelimeler: Hayvan refahı, hayvan bakımı, hayvanların muhafazası, İslam hukuku, ihsan, şefkat, zarar.

* I would like to thank Prof. Sarra Tlili for her constructive comments which helped me to improve my article. 


\section{Introduction}

With the development of animal studies, scholars have endeavored to approach animal care, animal protection, and animal welfare from a wide range of perspectives. Animal welfare and animal protection hold a central place in these studies, as they are deal with the needs and research areas of different disciplines. However, in these studies, less emphasis is given to how these concepts have been understood in different civilizations and how practices have evolved over the history of each civilization. Instead, this scholarship focuses on contemporary problems in animal welfare and animal protection and seeks solutions to them. However, the meaning and value placed on animals by a given civilization constitutes the very basis for all related subjects, including animal rights, welfare, and protection. In order, therefore, to understand the broader usage of these concepts, it is necessary to look at how the meanings evoked by these same concepts are interpreted in different cultures, both past and present, and the diverse dimensions and extensions of these meanings. Such a study will demonstrate that the meanings attributed to the concepts of animal rights, welfare, and protection differ with respect to time and civilizations. Beyond that, it will reveal what sort of shifts in meaning this concept has undergone and just how narrow the meaning imposed on it today is.

Studying the concepts of animal welfare and protection of animals in how they pertain to food and nutrition is only natural; however, restricting the value of animals to this does them a great injustice, as their very existence and raison d'etre extend far beyond this limited, subservient role. Indeed, reducing animals to suppliers of man's nutritional needs or examining animal welfare while emphasizing the dietary aspect will prevent us from gaining a holistic understanding of animal nature. Therefore, examining animal welfare, human-animal relations, and the historical connotations of gaining benefit from them will inevitably lead to our questioning the widespread understanding of animal welfare today. For this, it is important to investigate what the very term 'animal welfare' has evoked in different civilizations at different times, as this meaning shapes that culture's human-animal relationships and, therefore, animal welfare. ${ }^{1}$

1 The purpose of this study is not to conduct a comparative examination of the meaning attributed to animals or to the issue of animal welfare in different civilizations. I will focus more on animal welfare in Islamic civilization. However, performing comparative studies on the meaning that different civilizations have attributed to animals will contribute to a more lucid understanding of the subject. For example, Desmond Morris's work The Animal Contract sheds light on important information about how Europe has historically approached animals. Morris says, "At the end of the nineteenth century, the Catholic 
Understanding the meaning attributed to animals requires a more intimate look at what kinds of social and legal regulations have been made to ensure the welfare of animals throughout history, as these regulations embody how societies consider the place of animals in relation to humans. To elaborate, each regulation takes as its basis certain ontological premises and the same ontological grounds form the basis for an entire scholarly corpus. Although animals and animal welfare have been studied in various disciplines of Islamic scholarship (e.g., theology, mysticism, ethics, and philosophy), its concrete applications have referred to the framework drawn by Islamic jurisprudence. ${ }^{2}$ Therefore, this article aims to examine animal welfare in the context of Islamic jurisprudence in order to reveal the concrete applications of animal welfare and the foundations on which they are based.

\section{The Grounds of Animal Welfare in Islamic Civilization}

The Qur'ān and the Sunnah of the Prophet Muhammad constitute the grounds for Islamic civilization's approach to animals in general, and for animal welfare in particular. Being the primary texts for Islam, these two sources introduce the basic standards that delineate how Muslim societies should approach animals. These principles have determined and shaped both the meaning attributed to the animal as an ontological entity and the relationship that Muslims have established with animals over time. This relationship encompasses diverse areas ranging from law to daily life, from literature to theology, and from politics to economics. In each of these areas, the guiding principles that rule rely on the theoretical framework drawn from the Qur'àn and Sunnah. This orientation has paved the way for the conceptualization of several terms and statements mentioned in the Qur'ān and Sunnah in different disciplines and form the basis for social practices.

There are many concepts in the Qur'ān and Sunnah related to animals' basic existence as well as to the notion of animal welfare. However, the concepts I will focus on in this article are community (ummah), gentleness (rifq), excellence (iḥsān), and harm (darar). These same concepts are interrelated and intertwined in such a way

Dictionary was able to state categorically that animals 'have no rights. The brutes are made for man who has the same right over them which he has over plants and stones.' Astonishingly, the statement continues with the ultimate in callousness, declaring that it is 'lawful to put them to death, or to inflict pain upon them, for any good or reasonable end...even for the purpose of recreation'." See (Morris, 1990, p. 36). The approach in this dictionary, first published in 1897, shows how novel the concept of animal welfare is for Europe. See also (Steiner, 2010).

2 For a detailed discussion of different disciplines see (Foltz, 2005). 
that one concept cannot be thought of without the other. Therefore, when humananimal relations and animal welfare are examined without resort to these concepts, one misses the fuller picture. As a matter of fact, the diverse disciplines that emerged in Islamic civilization refer to these concepts while discussing animals, which I will address this in the following pages. Just as Islamic legal manuals, which constitute the focus of this article, construct the ethical and legal dimension of human-animal relations on these concepts, so too are the legal regulations issued in the Ottoman Empire based on these same concepts.

The theoretical approach to human-animal relations and the formation of a large corpus of works in this framework equally shaped the practice of Muslim societies in this regard. The legal regulations made regarding animals in the Ottoman Empire were shaped by the conceptual framework developed by Islamic jurisprudence. In this context, I will first look at how the Qur'ān and Sunnah handle both animals themselves and human-animal relationships, after which I will address the framework that Islamic jurisprudence has put forward on this subject through the aforementioned concepts.

\section{Animals as Communities like Us}

The Qur'ān provides an outline that sets out requirements for Muslims' relations with animals. In her study, Sarra Tlili goes into profound detail about this relationship. Beyond simply bringing together various Qur' ānic verses related to the subject, she provides information that reveals how these verses have been interpreted in Islamic exegetical tradition (tafsir) over the course of history. Tlili deals with animals in the Qur'ān through the concepts of subjugation (tadhlìl), serviceability (taskhìr), and vicegerency (istikhlāf) while emphasizing how these concepts evoke different dimensions of human-animal relations (Tlili, 2012).

The basis of these relationships is the fact that animals are creatures in the same vein as humans. This category of existence is articulated by calling them communities similar to those of humans in the Qur'ān (Sürat al-An 'ām, 6:38): "And there is no creature on the earth or bird that flies with its wings except [that they are] communities like you."3 This verse was revealed upon an objection raised by the polytheists against the Prophet Muhammad; the former teased the Muslims saying that "if Muhammad were really a prophet, why did Allāh not send a miracle (āyah) with him?" (Sūrat al-An ām, 6:37). This verse reminds people that if they were 
simply to look around them, they would be witness to many miracles, of which all animals are a part.

It is also important that the two words däbbah and tayr are mentioned in this verse. Whereas dābbah refers to the animals that live on the earth, țayr is used for all flying animals (Al-Jawharī, 1987, pp. 1:124, 2:727-729). Therefore, this verse clearly reveals that all animals in nature are communities like humans. Expressing that humans are not alone in the world, this verse also articulates that animals that are the creation most resembling humans.

Al-Tabarī (d. 310/923), one of the early Qur'ānic exegesis (tafsīr) scholars, states that birds, mankind, and the jinn are all their own communities (Al-Tabarī, 2000, p. 11:345). The nature of animals being a community like humans is the focus of many interpretations of this verse in Islamic exegetical tradition. For instance, 'Abdullāh Ibn 'Abbās (d. 68/688), one of the prominent Companions of the Prophet Muhammad and also his cousin, is reported to have said that animals' being communities like humans means that they understand and communicate with each other like humans (Al-Māturīdī, 2006, pp. 5:59-60). Made during the earliest stage in the history of Islam, this interpretation states that this similarity is that animals possess the same type of comprehension and communication skills as humans. Fakhr al-Dīn Rāzì (d. 606/1210) gathered seven views expressed by different scholars on this subject and interpreted them within the framework of their respective relationship with the verse. One of these views asserts that one dimension of this similarity with humans is that animals tend to be compassionate toward each other and reproduce gamogenetically; indeed, even the wildest animals show mercy to their offspring (Rāzì, 1420, p. 12:525). In this respect, there is no difference between humans and animals. These approaches have led to discussions in the disciplines of theology and philosophy on such issues as how animals communicate among themselves and, based on the compassion they show, the presence of emotions.

Within the Islamic exegetical tradition are certain tendencies explaining that the similarity between humans and animals is that God protects both of them. As a matter of fact, scholars of tafsìr, such as Zamakhsharī (d. 538/1144) and Qurțubì (d. $671 / 1273$ ), have interpreted this similarity to mean that animals are communities like humans and that they were created, like humans, through God's justice. For this reason, they reasoned that it is the responsibility of God to ensure the sustenance of animals, that He is fair to them, and that their death is determined by Allāh. Animals, like humans, will be returned to the Creator after their death. Since Allāh, the One who created them, protects and looks after them, people should not maltreat them 
or violate their rights (Al-Qurțubī, 1964, pp. 6:419-420; Al-Zamakhsharī, 1407, p. $2: 21$ ). This approach highlights that the creation of animals is by God and that just like is the case with humans, their sustenance is provided by Him. As an ethical result of this, they emphasized that cruelty to animals would not go unrequited. The basis for the legal protection against animal cruelty is how they are considered to be a human-like community in this verse. If maltreatment and cruelty toward animals is not requited in this world, it is agreed that their account will be settled in the hereafter.

There are also interpretations explaining the nature of the similarity between animals and humans as being a partial one rather than a total one. Accordingly, it is stated that animals are similar to humans in certain, if not all respects. For instance, it is narrated that Ibn 'Abbās stated that since animals resemble humans in that they also know God, regard Him as the only God, declare his incomparability, praise Him (Rāzì, 1420, p. 12:525). The Sufis' perspective on animals favors this approach. Indeed, many Sufis hold that since animals remember Allah and praise Him, they should be valued. This reveals that all creatures are valuable because they remember the Creator.

Another approach is highlighting the similarity between animals and some features of every human being on earth. Especially in the corpora of ethics and psychology, when examining the characters of people, reference is made to these common features between humans and animals. In this context, Fakhr al-Dīn Rāzì narrated from Abū Muhammad Sufyān Ibn 'Uyaynah (d. 196/811), a scholar from the Hijāz, that the praised and condemned characteristics of humans have counterparts in the basic characters of certain animals. For example, some people are like lions with their courage, some are like wolves with their hostility, and others are like peacocks with their adornments (Rāzī, 1420, p. 12:525). These similarities and the related connections between humans and animals were taken by some scholars as grounds for the theories expressed in the corpora of ethics and psychology on how to strengthen the positive aspects of the psyche, break bad habits, and replace them with virtuous ones (Al-Ghazzī, 2011, p. 11:266; Al-Khațțābī, 1399, pp. 53-58).

\section{Gentleness (Rifq) and Excellence (Iḥsān) in Relations with Animals}

As I mentioned above, the Qur'ān refers to animals as a community like humans. How this statement reflects on human behavior can be observed strikingly in the life of the Prophet of Islam. The first examples of how to establish a relationship with animals can be found in his life. When it comes to relationships with animals, 
two concepts come to the fore: gentleness (rifq) and excellence (iḥsān). These two concepts are central in his own relationship with animals and his reactions to how people around him interacted with animals. Here, I will briefly dwell on some examples of this.

There are a number of examples from the life of the Prophet Muhammad that act as the basis of Muslims' approach toward animal welfare. One of these examples relates to his wife 'A' isha's behavior toward a camel. Once, while riding a rowdy a camel, 'A' isha began to drive the camel back and forth harshly. When the Prophet observed her behavior toward the camel, he asked her to be merciful to the camel saying, "You must be gentle." "The word rifq used in the hadith (plural: ahäaith) is based on the perception of animals as constituting communities like human beings in the Qur'àn. As I mentioned above in detail, the Qur'àn provides the grounds for Muslims to consider animals as communities. The Prophet Muhammad, as the first interpreter and practitioner of Qur'ānic principles, asked his followers to establish human relations with them with gentleness. Rifq is a qualification that beautifies the person who possesses it and leads to many virtuous behaviors. Consequently, it is a feature that people must have and that should be present in their engagement with each other and in their behavior toward animals, plants, and other things (Ibn al-Jarrāh, 1984, pp. 776-781). The Prophet's hadìth shows that he was trying to inculcate this feature in people, starting with the closest person, his wife 'A' isha.

An important point here is that when it comes to animals the concept of rifq is employed in the same sense, without any change, as that in human relations. The Prophet Muhammad made several recommendations on many occasions in order to give advice on how his companions should behave with animals. In one of these pieces of advice, he mentioned the story of a thirsty man and a dog. The hadith is as follows (Al-Bukhārī, 1422, Kitāb al-Adab no. 27):

Allāh's Apostle (Peace be upon him) said, "While a man was walking, he felt thirsty and went down a well and drank water from it. On coming out of it, he saw a dog panting and eating mud because of excessive thirst. The man said, "This dog is suffering from the same problem of thirst as that of mine. So, he went down the well, filled his shoe with water, caught hold of it with his teeth and climbed up and 
watered the dog. Allāh thanked him for his good deed and forgave him." The people asked, 'O Allāh's Messenger! Is there a reward for us in serving animals?' He replied, 'Yes, there is a reward for serving any living being.'

This means that the expression “communities like you” in the Qur' ān requires relations with animals to be based on rifq, just as is the case for relationships with humans. This was manifested clearly in the life of the Prophet Muhammad.

There are several examples of animal mistreatment that caused rebuke and intervention by the Prophet. Stating that rifq must underlie all relationships with animals, the Prophet Muhammad strongly warned against their mistreatment. These warnings and his attitude toward one's behaviors toward animals constitutes the basis for legal regulations in later periods. According to one of these ahädith, the Prophet passed by a very weak camel whose stomach was almost touching its back due to malnourishment. Upon seeing this, he said, "Fear God regarding these mute animals!" ${ }^{\circ}$ As is emphasized in the commentaries on this hadith, because animals do not have the capacity to express their wishes and needs to humans, people should treat them as living beings and realize that they also have needs. Based on this Prophetic warning, scholars have stated that animal owners are obliged (wäjib) to provide food and drink for animals and if they fail to do so, they will be compelled by the government/court (Al-Qārī, 2002, pp. 6:2204-2205). I will examine the legal regulations that prevent animal owners from starving their animals below. Before that however, I would like to mention another aspect of the issue here.

Islamic civilization has endeavored to ground people's relations with animals on the concept of excellence (iḥsān) without resorting to legal obligation. Ihsān is infinitive verbal noun (mașdar) derived from the word husn, which means goodness and beauty. It means doing good, working in the best way, and as explained by the Prophet Muhammad, living life and worshiping God as if you see Him, for though you do not see Him, He surely sees you. Accordingly, the Prophet teaches Muslims to perform all of their deeds as best as they possibly can-as if God were right in front of them. Looking at these meanings of ihsān, it is clear that goodness and beauty should be extended to all parts of life. For this reason, people need to develop a relationship based on ị̂sān not only with each other, but also with other creatures of Allāh, especially animals. The first and most exemplary applications of ị̣sān are 
to be found in the life of the Prophet Muhammad, where it can be seen that ihsān holds a central place in his relations with animals.

Violence toward animals is strictly forbidden, since excellence (ị̣sān) requires treating animals with gentleness (rifq) and kindness (Al-Sakhāwī, 1994, pp. 65-70). There are several examples in the life of the Prophet Muhammad where he reacted strongly against violence toward animals. He forbade the beating and branding of an animal's face; ${ }^{6}$ once he passed by a donkey marked so badly on its face that it had caused serious distortion. The Prophet said, "Curse be upon that person who distorted the face of this poor animal."7 The fact that the reaction of the Prophet Muhammad was so vehement, considering that he cursed others very rarely in his life, shows the importance of preventing animals from suffering as a result of human cruelty. In addition, there is no difference in hitting or causing damage to the face of an animal, since all of the senses of people and animals (e.g., seeing, tasting, and hearing) are located in the face (Al-Qurțubī, 1996, p. 5:437). Therefore, there is no difference between humans and animals regarding this prohibition and severe warning.

Being the norm in the human-animal relationship in the Islamic point of view, excellence (ihsān) renders it possible to go beyond forbidding bad behavior toward animals to prohibiting even verbal abuse. Although animals and humans do not speak the same language, the quality of a person's behavior toward them is considered primarily as an indicator of his/her own character. Therefore, excellence (ihssān) obliges the virtuous person to treat others, including animals, well. For this reason, the Prophet Muhammad forbade the use of expressions that would humiliate or harm their dignity, let alone their mistreatment. In another incident, a woman who became angry with the camel she was riding during a journey cursed it, upon which the Prophet Muhammad asked her to unload the camel and set it free (Al-Qushayrī, 1995, Kitāb al-Birr no. 80). The Prophet Muhammad has forbidden the cursing of humans, animals and things in general. Due to the wide scope of this prohibition, which also includes non-living things, it has been acknowledged that animals should be treated with excellence (iḥsān) and may not be abused through cursing. ${ }^{8}$ 


\section{Transformation of Gentleness (Rifq) and Excellence (Ihssān) into Harm (Darar) in Legal Discourse}

Terming animals as a community similar to that of humanity in the Qur'ān led the earliest Muslim scholars to address animals on a scholarly level across a broad range of subjects, including philosophy, theology, ethics, jurisprudence, and psychology. There are several reasons as to why animals have been addressed in various Islamic sciences. The first motivation was to gain knowledge of the question of existence, which led scholars to study animals as a category of being in philosophy and theology. The second reason is that Muslims encountered a variety of animals in the large stretches of lands in which they inhabited, from China to Europe and from the edge of Saharan Africa to Northern Russia, and this led to an increased interest in learning about them. The third reason is that animals are connected with various Islamic rituals that are performed during specific stages of one's life. Because worship in the form of alms, pilgrimage, sacrifice, and expiation for sins involve the use of animals, multi-dimensional research was conducted on animal-related subjects. In addition, the importance as to whether the means used to hunt or to obtain medicine from animals are halāl (religiously licit) has been the impetus for many studies.

All of these factors are related to subjects studied under Islamic jurisprudence. Throughout the course of history, the injunction that animals are societies like human beings and that mercy is to be at the core of humans' relations with them has influenced the rulings of Muslim jurists. Accordingly, scholars have studied subjects such as the protection of animals, the rights of animals held as property, compensation for losses caused by animals, and animal welfare. Though I will focus on animal welfare, before dealing with this, I would like to briefly touch upon how animals are considered as a category of existence in Islamic thought.

Before moving on to how this issue is studied in Islamic thought, it needs to be emphasized that certain scholarly discourses from within the field of animal studies are currently debating whether Islamic thought is anthropocentric (Foltz, 2005, pp. 146-150; Tlili, 2012). As a concept in the field of environmental ethics and environmental philosophy, anthropocentrism is related to ecosystem destruction, environmental degradation, and pollution caused by humans. Also, the discussion of the subject of animal in the context of anthropocentrism coincides with the beginning of the $20^{\text {th }}$ century (Moore, 1906). Therefore, the implications in the anthropocentrism debates are largely related to environmental destruction and the negative attitudes of humans toward non-human beings. Therefore, the question of anthropocentrism emerged in part from the nature divide that exists in Western 
philosophy and environmental thought. Since the issue at hand is related to Western thought and philosophy, it must be stressed that cultures of other civilizational settings may very well have completely different paradigms, categories, and practices. It is problematic to discuss Muslims' relationships with non-humans, especially objects (ashy $\left.\vec{a}^{\prime}\right)$ and animals, based on a concept molded in a Western context with its categorically different thoughts and values vis-à-vis human-animal relations. Although the primary sources of Islam state that the world is offered up to serve humans, many principles were also set out to prevent people from acting irresponsibly and harming animals and non-living beings in the world. Therefore, it is anachronistic to claim that Islamic thought is anthropocentric and to examine the animal-related issues in this context. Non-anthropocentric readings of the Qur'ān and Sunnah are a contemporary approach that does not offer a holistic view about the experience of pre-modern Muslim societies.

The subject of the animal is covered in a comprehensive manner in the works of Islamic theology, philosophy, and mysticism that deal with the ontological levels or spheres of being (marātib al-wujūd). ${ }^{9}$ In this context, Muslim scholars study life under three categories, that is, vegetal souls, animal souls, and human souls. ${ }^{10}$ This approach is based on the hierarchy that all beings are classified as contributing to a higher purpose, that is, that each ontological level of being seeks to excel to a higher level through serving as the foundation of the next higher level and thereby mature into a state of perfection (kamālāt). According to this philosophical treatment and anthropic principle in that everything is related to everything else, the main features of the vegetal soul are reproduction, nutrition, and growth. These three features are also existent in the human and the animal soul. However, the physical matter of plants has been made into nourishment for the physical matter of animals and a means for animals' subsistence. In this way, the vegetal soul has the function of are expressed as God, angels, humans, animals, plants, and elements. According to some scholars, there is a hierarchy in these categories, while for others, there is not. However, the important point here is that according to both approaches, beings have their own value simply because they exist. For this reason, the humans' relations with other beings, such as the elements, plants, and animals, is based on the idea that these beings have values based on their existence. For detail discussion of the subject see (Al-Jili, 1999; Al-Shīrāzī, n.d., vol. 8; Ibn 'Arabī, n.d.).

10 Muslim philosophers made original contributions to this classification that they had inherited from the philosophers of the Hellenistic period. Aristotle, for instance, divides creatures into three subrealms, i.e., plants, animals, and human beings. According to him, plants have a vegetal soul, animals have a sensitive soul, and human beings have a rational soul. He categorizes these three levels based on their value and lack thereof (Aristotle, 2016, pp. 26-27). 
being subservient to the animal soul. The animal soul, however, realizes particular (juz' $\bar{l} / j u z$ 'iyyāt) forms of existence and acts with a free will. Animals, by their very nature, have the faculty of sensation (ihsas) and the power of voluntary movement (al-harakat al-irādiyya). However, the rank of the animal soul is less than that of the human soul because it is subservient to the rational soul. As the ultimate and highest rank in common existence, the human soul comprehends both universals (kullī/kulliyyāt) and abstract particulars. The human is more sophisticated than the first two categories in terms of its intellectual and intuitional capacity (Al-Shīrāzī, n.d., p. 8:106; Türker, 2006, p. 529). Of course, these features that humans possess mean that they have intellectual faculties different from animals and are superior with respect to this capacity. It does not mean that human beings can treat animals as they wish, or that they can be cruel to them. ${ }^{11}$

The animal soul (al-nafs al-ḥayawānī) has two more distinctive faculties, namely the power of perception (al-quwwa al-mudrika) and power of motion (al-quwwa almuharrika), in addition to the reproduction, nutrition, and growth possessed by the vegetative soul (al-nafs al-nabātì). These two features are the basic elements that distinguish animals from plants. The power of perception is the external faculty consisting of the five senses (i.e., sight, hearing, touch, smell, and taste). With this faculty, animals comprehend what is happening around them in the physical world. The second faculty is the internal senses, which include common sense, imagination, illusion, memory, and representation. Common sense is the faculty by which the particular perceptions perceived by the five external senses are collected. Imagination functions to collect and store previously seen and lost objects in the common sense. The power of illusion is the ability to grasp concepts not perceived by the senses. Memory is the power that protects particular meanings grasped by the power of illusion. Representation is the power that combines and separates the senses and the particular meanings derived from them (Türker, 2006, p. 530). ${ }^{12}$ When all these powers are together, animal soul reveals its characteristics that differ it from plants.

11 This distinction between human and animal made it necessary to establish a gentleness-based relationship with animals in Islamic civilization. However, this distinction had a different result in other civilizations. The approach of Spinoza, one of the philosophers of the Enlightenment, toward animals can be given as an example. According to him, humans have a natural "right" to kill and make use of animals in any way that is advantageous to them. Although animals have sensations, humans may consider their own advantage, use animals at their pleasure, and treat them as is most convenient for humans. (Spinoza, 1994, p. 219). See also (Nadler, 2006, p. 198).

12 For a detailed discussion about animals in the history of Western philosophy see (Ryan, 2015). 
Other disciplines have continued this philosophical and theological approach toward animals, adopting it to their own fields. For example, in the books on ethics, the faculties specific to animals (i.e., sense and will) are contemplated in order to present their human-like and non human-like aspects. In his famous work Ahlāk- $\imath$ 'Alā' $\bar{\imath}$ (Sublime Ethics), the Ottoman moral and political thinker Ḳınalizāde 'Ali Çelebi (d. 979/1571) states that the soul is divided into three types by the philosophers, namely, the vegetative soul, animal soul, and human soul. After that, he examines the animal soul within the framework of the characteristics emphasized by philosophers, delving deeply into the relationship with human and animal souls (Ali Çelebi, 2007, pp. 62-63).

The juristic discourse on animal welfare in Islamic law is based on the sensitivity that animals are communities like human beings. We have seen above that this requires relationships grounded in gentleness ( $r i f q$ ) and excellence (ihssān). Now, I will focus on how this relationship is maintained in the legal discourse with respect to interaction with animals. ${ }^{13}$ The legal complement of the gentleness (rifq) and excellence (ihsān) based relationship is the concept of harm (darar) in Islamic law. One of the important bases of harm (darar) is the hadith stating that "no harm (darar) should be inflicted or reciprocated," which prohibits subjecting oneself to harm and causing harm to others (Ibn Anas, 1985, Kitāb al-Aqḍiya no. 31). The elimination of harm (darar) is another mega principles on which Islamic law is based (Ibn Nujaym, 1999, pp. 72-73). Although this principle is more often mentioned in human relations, reference is also made when it comes to animal issues.

In the $7^{\text {th }} / 13^{\text {th }}$ century, people carried their loads on animals and traveled by riding them. ${ }^{14}$ The famous Shāfi $\overline{1}$ jurist and hadìth scholar al-Nawawī (d. 676/1277) highlighted key points to determine the principles underlying the use of animals for carriage and riding. Accordingly, it is not permissible for one to overly burden his/ her own animal or an animal that was rented to carry a load beyond the animal's capacity. ${ }^{15}$ According to him, it is impermissible for those who rent out their animals to tolerate a heavy burden on them. ${ }^{16}$ Al-Nawawi based his view on the

13 Referring to some Prophetic traditions, some scholars state that human-animal relations must be based on mercy and excellence. See (Al-Sakhāwī, 1994, pp. 53-56).

14 For this function of animals see (Mikhail, 2010, pp. 621-652).

15 Burdening animals beyond their capacity was acknowledged as prohibited (harām) by Muslim scholars. See (Al-Sakhāwī, 1994, p. 40).

16 In the period during which al-Nawawī lived, "Farm animals were treated brutally but remained important sources of food. Beasts of burden were worked until they dropped” in Europe. See (Morris, 1990, p. 35). 
ahädìth he reported on the subject: "Verily, God has prescribed excellence (ihsān) in everything," "No harm (darar) should be inflicted or reciprocated," and "Fear Allāh regarding these mute animals." (Al-Nawawī, n.d., pp. 4:390-391). Although al-Nawawi discusses the legal aspect of the subject, he deals with it in the context of two basic principles, excellence (ihsān) and prevention of harm (darar), rendering it possible to conclude that the legal rulings on human relationship with animals are based on these two principles.

The $8^{\text {th }} / 14^{\text {th }}$ century North African Mālikī jurist Ibn al-Haàjj al- 'Abdarī (d. 737/1336) emphasized that a person carrying a load on an animal or using an animal as a mount should allow the animal to rest in the morning and the evening. In addition, Ibn al-Hājj touched on the issue of sleeping on the animal, as doing so was a common practice in certain places during his lifetime, stating that it must be avoided. According to him, when an animal is rented, the renter is prevented from riding it if he/she places too much of a load on to it. Supporting this view from several different vantages, Ibn al-Hājj states that this is above all against the Prophet's Sunnah. It is forbidden to overload an animal beyond its capacity or to treat it in such a way that causes it harm (Al-Abdarī, n.d., p. 4:47). The emphasis is placed on doing this so as not to harm animals when using them to meet people's needs. All of these behaviors (i.e., allowing animals to rest, not overloading them, and not harassing them) are related to the basic Islamic principle of preventing harm (darar). Therefore, Ibn al-Hājj, like other Muslim jurists, underlined this same principle of preventing harm (darar) in people's relations with animals.

The Central Asian Ḥanafī jurist of $6^{\text {th }} / 12^{\text {th }}$ century al-Kāsānī (d. 587/1191) pointed to the theoretical and moral dimensions of the principle of preventing harm (darar) and though he stressed the consequences to be faced in the Hereafter for violating this principle, also mentioned the punishments for its violation in this world. He cited issues such as overloading rented animals, traveling on them without a break, and using them in violating any of the agreed-upon terms and conditions specified in the rental contract. Accordingly, if an animal is to be harmed either by violating the agreed-upon terms of the contract or due to mistreatment, the person who causes harm must pay compensation for it. The amount of this compensation is determined based on the damage done (Al-Kāsānī, 1986, pp. 4:213-214). As it is seen in al-Kāsānī's discussion, Muslim jurists not only examined the issue, ruling that harming animals is forbidden and impermissible but also stated that this harm needs to be compensated for, and posited legal sanctions on injuring animals. 
The principles of gentleness (rifq), excellence (ihssān), and harm (darar) as they pertain to animals are not only principles that prevailed in daily and commonplace relationships with animals; these principles were also to be observed during times of war. It is important to maintain the welfare of animals during war, despite its being a period when normal relations are put aside, and people develop hostile relations toward each other. In this context, Muslim jurists denounced leaving animals thirsty and hungry or killing them without reason. According to them, such acts are unlawful, even during times of war. For example, Ibn Hajar alHaytamī (d. 974/1567) states that killing a vulnerable animal is unlawful and that no owner has the right to leave an animal thirsty and hungry. ${ }^{17}$ Muhammad al-Shirbini (d. 977/1570) clarifies the subject even further, stating that even during wars the matter has two dimensions:

The inviolability of animals has two bases: The right of the owner and the right of God. Although the unbelief of the owner or taking sides with the enemy invalidates their right of ownership on the animal during times of war, the right of inviolability continues as a right of God. Therefore, the owner has no right to leave the animal thirsty or hungry. ${ }^{18}$

\section{Conclusion}

Animal welfare is often discussed in the context of animals' being regarded as foodstuff. However, the human-animal relationship has meaning beyond this. However, this relationship has appeared in diverse ways in different civilizations. In Islamic civilization, the Qur'àn and Sunnah determine how this relationship should be and term animals as communities (umam) similar to humans. The recognition of animals as a community like humans forms the very basis of human-animal relations. This has led to the maintenance of human-animal relations based on gentleness (rifq), excellence (ihsān), and prevention of harm (darar). However, as well as the theoretical dimension of this relationship, the kind of differences in practice in which it has resulted is also important.

17 See (Ibn Hẹajar al-Haytamī, 1989, p. 9:246).

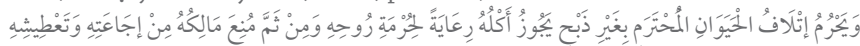

18 See (Al-Shirbīnī, 1994, p. 6:37).

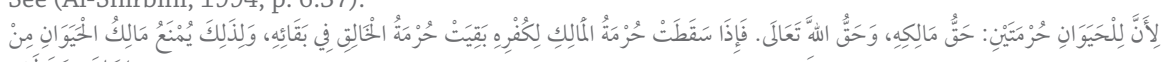
إِجَاعَتِهِ وَعَطَشِهِ 
As discussed above, animals are considered their own ontological level of being in Islamic civilization, which has led to many important rulings and practices in Muslim cultures. Discussion of animals in different disciplines is among these, as each discipline developed an approach toward animals emanating from its own methods. However, the common point in all these approaches is that animals are considered to be a community. When discussing the theoretical aspect of the issue, the meaning and limits of being a community were discussed in particularly great detail. Therefore, questions such as to whether animals have a soul, whether their behaviors are intentional, and whether they have moral responsibility were all addressed. In addition to this theoretical dimension, the question regarding the role of humans in human-animal relations has been examined in Islamic jurisprudence.

Muslim jurists deal with the subject of animals under various chapters in legal manuals. In discussing the subject in these chapters, greater focus is given to humananimal relations and humans' utilization of animals. Although the limits of this utilization are being debated in contemporary animal studies today, Muslim jurists have considered it to be à priori for humans to benefit from animals since no such consideration existed prior to the $19^{\text {th }}$ century in the Western world. Scholars have discussed the limits of benefiting from animals, whether human beings may behave arbitrary in this regard, and what the legal consequences of harming animals should be.

Muslim jurists have acknowledged that people must exhibit gentleness (rifq) when making use of animals. They took this further and emphasized that it is not be enough to be gentle, excellence (ihsann) should be the base of the relationships in every dimension of human life, including in their dealings with other humans, animals, and all non-living things. They argued that if animals are used to complement human bodily strength, it should be done so in such a way that no harm (darar) is caused to animals. Even if all precautions are taken, there are various legal opinions on how to compensate when harm befalls an animal. These legal debates show that human-animal relations are based on certain vital principles in Islamic civilization and not left to people's whims and desires.

\section{References | Kaynakça}

Al-'Abdarī, A. 'Abd A. M. ibn al-Hājj. (n.d.). al-Madkhal. al-Qāhirah: Dār al-Turāth.

Al-Bukhārī, M. ibn I. (1422). Ṣaḥịh al-Bukhārī. Bayrūt: Dār Ṭawq al-Najāh.

Al-Ghazzī, N. al-D. M. ibn M. (2011). Ḥusn al-tanabbuh li-mā warada fī al-tashabbuh. Bayrūt: Dār al-Nawādir. Al-Jawharī, I. ibn H. (1987). al-Ṣiḥāḥ: Tãj al-lughah wa-ṣiḥāḥ al-'Arabīyah. Bayrūt: Dār al-'Ilm lil-Malāyīn. 
Al-Jilī, A. al-K. (1999). Marātib al-wujūd wa haquiqqat kull mawjūd. al-Qāhirah: Maktabat al-Qāhira.

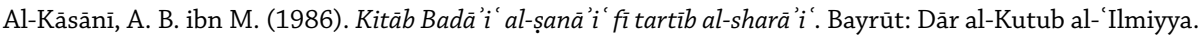

Al-Khațțābī, H. ibn M. (1399). al-'Uzlah. al-Qāhirah: al-Mațba ah al-Salafĩyah wa-Maktabatuhā.

Al-Māturīìi, A. M. (2006). Ta’ wīlāt al-Qur’ān. Istanbul: Dār al-Mīzān.

Al-Nawawī, A. Z. M. al-D. ibn S. (n.d.). al-Majmū’ sharh al-muhadhdhab. Bayrūt: Dār al-Fikr.

Al-Qārī, 'Alī ibn Muḥammad. (2002). Mirqāt al-mafātīh sharh Mishkāt al-mașābīh. Bayrūt: Dār al-Fikr.

Al-Qurțubī, A. 'Abd A. M. ibn A. (1964). al-Jāmi 'li-aḥkām al-Qur'ān. al-Qāhirah: Dār al-Kutub al-Mișriyyah. Al-Qurțubī, A. ibn 'Umar. (1996). al-Mufhim li-mã ashkala min talkhịs Kitāb Muslim. Dimashq: Dār Ibn Kathīr. Al-Qushayrī, M. ibn al-H. (1995). Șaḥiḥ Muslim. Bayrūt: Dār Ibn Ḥazm.

Al-Sakhāwī, M. ibn 'Abd al-R. (1994). Juz' Tahrīr al-jawāb 'an mas'alat ḍarb al-dawāb. Bayrūt: Dār Ibn Ḥazm. Al-Shīrāzī, S. al-D. M. (n.d.). al-Hikmah al-muta' āliyah fi al-asfär al-arba 'ah. Bayrūt: Dār Ihyyā’ al-Turāth al-'Arabī. Al-Shirbīnī, S. al-D. M. ibn M. al-K. (1994). Mughnī al-muhtāj ilī ma rifat ma'ānī alfāz al-Minhāj. Bayrūt, Lubnān: Dār al-Kutub al-'Ilmīyah.

Al-Sijistānī, A. D. S. ibn al-A. (1998). Sunan Abī Dāwūd. Bayrūt: Dār Ibn Ḥazm.

Al-Ṭabarī, M. I. J. (2000). Jāmi' al-bayān fì ta’ wìl al-Qur'ān. Bayrūt: Mu’assasat al-Risālah.

Al-Zamakhsharī, A. al-Q. M. ibn 'Umar. (1407). al-Kashshāf' an ḥaqua 'iq al-tanzīl. Bayrūt: Dār al-Kitāb al-'Arabī. ‘Ali Çelebi, K. (2007). Ahlāk-ı 'Alā'ì. İstanbul: Klasik Yayınları.

Aristotle. (2016). De Anima. New York: Oxford University Press.

Foltz, R. (2005). Animals in Islamic Tradition and Muslim Cultures. Oxford: Oneworld Publications.

Ibn al-Jarrāḥ, W. (1984). Kitāb al-Zuhd. al-Madīnah al-Munawwarah: Maktabat al-Dār.

Ibn Anas, M. (1985). al-Muwațța'. Bayrūt: Dār Ihyyā' al-Turāth al-'Arabī.

Ibn Ḥajar al-Haytamī, S. al-D. A. al-'Abbās. (1989). Tuḥfat al-muhtāj fi sharh al-Minhāj. al-Qāhirah.

Ibn 'Arabī, M. (n.d.). Fușūṣ al-ḥikam. Bayrūt: Dār al-Kitāb al-'Arabī.

Ibn Nujaym, Z. al-D. ibn I. (1999). al-Ashbāh wa-al-naẓa ìr. Bayrūt: Dār al-Kutub al-'Ilmīyah.

Mikhail, A. (2010). Animals as Property in Early Modern Ottoman Egypt. Journal of the Economic and Social History of the Orient, 53(4), 621-652.

Moore, J. H. (1906). The Universal Kinship. Chicago: Charles H. Kerr \& Co.

Morris, D. (1990). The Animal Contract. London: Virgin Books.

Nadler, S. (2006). Spinoza’s Ethics, An Introduction. New York: Cambridge University Press.

Rāzī, F. al-D. M. ibn 'Umar. (1420). Mafātīh al-ghayb. Bayrūt: Dār Ihyā' al-Turāth al-'Arabī.

Ryan, D. (2015). Animal Theory, A Critical Introduction. Edinburgh: Edinburgh University Press.

Spinoza, B. de. (1994). A Spinoza Reader: The Ethics and Other Works. E. Curley (Ed.). New Jersey: Princeton University Press. 
insan \& toplum

Steiner, G. (2010). Anthropocentrism and Its Discontents: The Moral Status of Animals in the History of Western Philosophy. Pittsburgh: University of Pittsburgh Press.

Tlili, S. (2012). Animals in the Qur'an. New York: Cambridge University Press.

Tlili, S. (2015). Animals Would Follow Shäfi ism: Legitimate and Illegitimate Violence to Animals in Medieval Islamic Thought. In R. Gleave \& I. T. Kristó-Nagy (Eds.), Violence in Islamic Thought from the Qur'ān to the Mongols (pp. 225-244). Edinburgh: Edinburgh University Press.

Türker, Ö. (2006). Nefis. In Diyanet Vakfi İslam Ansiklopedisi (DİA) (pp. 32: 529-531). İstanbul: TDV Yayınları. 